\title{
ANALISIS KAPASITAS DAN KEKUATAN KONSTRUKSI BLADDER TANK PADA SIRKULASI AIR PANAS SISTEM ORC SOLAR KOLEKTOR R-134a
}

\author{
Irsan Novianto ${ }^{1}$, Yogi Sirodz Gaos ${ }^{1}$, Hablinur Alkindi ${ }^{1}$ \\ Program Studi Teknik Mesin, Fakultas Teknik, \\ Universitas Ibn Khaldun Bogor \\ Email : irsannovianto21@gmail.com
}

\begin{abstract}
This study focused on component in the Organic Rankine Cycle (ORC), Bladder Tank. The calculation method is based on the calculation stage of plate thickness to withstand the pressure caused by the circulation of the ORC system. The material used is SA 106 with $12 \mathrm{~mm}$ thickness, Shell length $600 \mathrm{~mm}$, $270 \mathrm{~mm}$ inner diameter and $95 \mathrm{~mm}$ Head length. From the calculation results obtained maximum pressure on Shell $=253,8385$ psi $(17,7$ bar g) and pressure at Head equal to $=249,6983$ psi $(17,2$ bar g). Bladder Tank Capacity of $38055622,5 \mathrm{~mm}^{3}$ (38,0556 Liter). From result of Pressure Drop simulation got Head loss equal to $=0,00000066 \mathrm{~m}$.
\end{abstract}

Keywords: Pressure Vessel, Pressure, Head Loss

\section{Pendahuluan}

Dengan semakin berkembangnya masalah yang diakibatkan oleh pemanasan global, kebijakan energi berkelanjutan (sustainable energy) semakin mendapat perhatian yang luas. Kebijakan ini mempunyai dua kata kunci, yaitu peningkatan efisiensi energi dan usaha-usaha mencari sumber-sumber energi baru dan terbarukan. Sebuah inovasi untuk dapat memenuhi kebutuhan akan ketersediaan listrik salah satunya adalah Organic Rankine Cycle disingkat $O R C, O R C$ dikembangkan oleh William john macqourn rankine pada desember 1872 ORC merupakan siklus pembangkit listrik yang menggunakan air sebagai fluida kerja. Siklus ORC dapat disesuaikan dengan kisaran suhu yang besar untuk menghasilkan energi, terutama untuk energi pada suhu rendah di bawah $120^{\circ} \mathrm{C}$. Sistem ini menggunakan temperatur dan tekanan rendah untuk menghasilkan uap refrigeran yang digunakan untuk menggerakan turbin yang terkopel dengan generator yang selanjutnya akan mampu menghasilkan energi listrik.

Dalam penelitian sistem ORC penulis terfokus pada salah satu komponen yaitu Bladder Tank. Metode penelitian yang digunakan adalah dengan cara manual (hand calculation) dengan formula berdasarkan standar ASME maupun analisa komputer.

\section{Bladder Tank (Bejana Tekan)}

Bladder Tank (Bejana Tekan) adalah tempat untuk menampung sementara suatu fluida baik yang berupa cairan maupun gas. Bejana tekan dibangun dengan persyaratan kekuatan dan kestabilan konstruksinya. Kekuatan suatu struktur dihitung berdasarkan tegangan maksimum yang terjadi pada struktur tersebut berdasarkan beban operasi yang diterimanya. Tegangan yang terjadi pada dinding bejana sering disebut dengan tegangan membran, yang mempunyai tiga arah utama yaitu; tegangan hoop, tegangan meridian, dan tegangan radial.

Bladder Tank terdiri dari beberapa bagian utama seperti; dinding (shell), kepala bejana (head), lobang orang/lubang pembersih (manhole), nosel-nosel (nozzles), dudukan penyangga (support) dan aksesoris lainnya yang digunakan sebagai alat pendukung, baik komponen yang berada di dalam maupun luar. Adapun material atau bahan yang digunakan untuk membuat bejana tekan ini adalah pelat baja yang terlebih dahulu direncanakan dan dihitung ketebalan pelat yang akan digunakan dan spesifikasi material yang akan direncanakan didalam proses pabrikasi pembuatan bejana tekan ini. Sistem penyambungan yang digunakan antara komponen yang satu dengan yang lainnya digunakan sistem pengelasan.

\section{Klasifikasi Bladder Tank}

Klasifikasi bejana tekan di bagi menurut posisi atau tata letak bejana tekan yang terdiri dari dua macam posisi yaitu : posisi vertikal dan posisi horizontal.

\section{Posisi Tegak (vertical)}

Posisi vertical yaitu posisi tegak lurus terhadap sumbu netral axis, dimana posisi ini banyak 
digunakan didalam instalasi anjungan minyak lepas pantai (offshore), yang mempunyai tempat terbatas

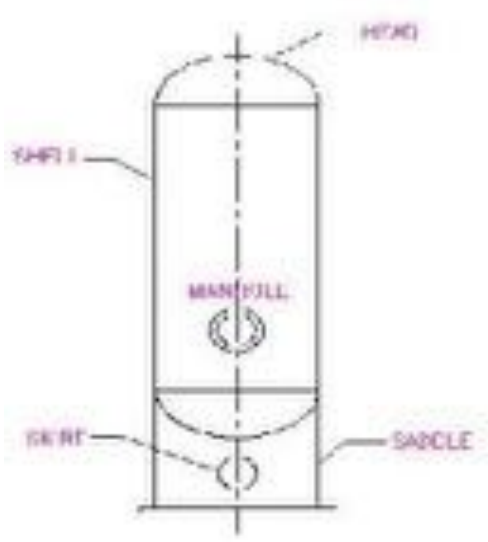

Gambar 1 Bejana Tekan Vertical

2. Posisi datar (horizontal)

Bejana tekan pada posisi horizontal banyak ditemukan dan digunakan pada ladang sumur minyak didaratan karena mempunyai kapasitas produksi yang lebih besar

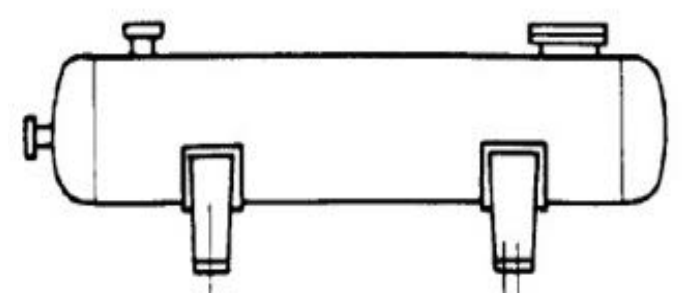

Gambar 2 bejana tekan horizontal

\section{Komponen Utama Bladder Tank}

Bejana tekan terdiri dari berbagai macam komponen utama dan pendukung, yang mempunyai fungsi masing-masing untuk menunjang operasi. komponen-komponen bejana tekan antara lain shell, head, manhole, nozzle/ opening, flanges, leg supports, lifting lugs.

\section{Shell}

Komponen terbesar pada sebuah bejana adalah Shell, yaitu dinding utama dari sebuah Bejana atau dapat juga disebut sebagai badan bejana yang berfungsi sebagai tempat kedudukan nosel dan juga komponen lainnya, selain itu shell juga sebagai pembentuk utama bejana. Tekanan yang bekerja pada Shell adalah Circumferential Hoop Stress dan Longitudinal Stress.

1) Circumferential Hoop Stress

$$
t=\frac{p \times D_{i}}{S \times 2}
$$

\section{2) Longitudinal Stress}

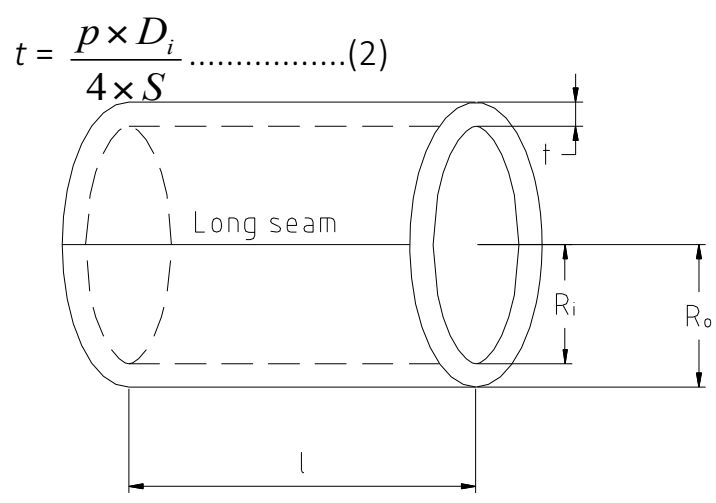

Gambar 3 Shell of Bladder Tank

Perhitungan bejana tekan terdapat beberapa standar yang di tentukan, salah satunya berdasarkan standar ASME section VIII div 1 . Berikut merupakan perhitungan standar yang ditentukan berdasarkan ASME section VIII div 1

a. Perumusan dalam kaitan dengan dimensi dalam (internal dimensions)

$\Rightarrow$ Ketebalan minimum dinding bejana "Shell "( tmin )

$$
\mathrm{t}_{\min }=\frac{p R_{i C A}}{S E-0,6 \mathrm{p}} .
$$

$\Rightarrow$ Tekanan kerja Maksimum ( pmax )

$$
\mathrm{p}_{\text {max }}=\frac{S E t_{\text {min }}}{R_{1}+0,6 \mathrm{t}_{\text {min }}}
$$

b. Perumusan dalam kaitan dengan dimensi luar ( outside dimensions )

$\Rightarrow$ Ketebalan minimum dinding bejana Shell" (tmin )

$$
\mathrm{t}_{\min }=\frac{p R_{o}}{S E+0,4 \mathrm{P}}+\mathrm{C} \cdot \mathrm{A} .
$$

$\Rightarrow$ Tekanan kerja Maksimum ( pmax )

$$
\mathrm{p}_{\text {max }}=\frac{S E t_{\text {min }}}{R_{o}-0,4 \mathrm{t}_{\text {min }}}
$$


c. Volume of Shell

Volume silinder dapat dihitung dengan menggunakan rumusan

$v=\pi \times r^{2} \times t$

\section{Head}

Ciri utama dari sebuah bejana tekan atau bejana bertekanan yang terklasifikasikan sebagai bejana tertutup (Closed Vessel) adalah memiliki head(kepala/ujung penutup bejana). Head berfungsi sebagai penutup bejana. Material yang digunakan pada head harus mempunyai stress value, komposisi kimia yang sama ataupun sejenis dengan material yang digunakan pada shell, karena akan berpengaruh pada proses pengelasan yang bertujuan untuk menyatukan antara Head dengan Shell.

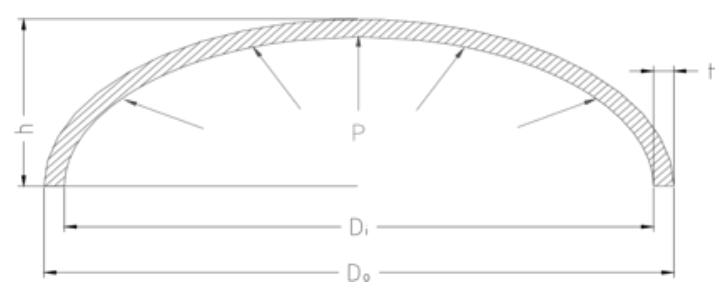

Gambar 4 Ellipstical Head

Jenis Head yang digunakan dalam penelitian ini adalah Ellipstical Head. Berikut merupakan perhitungan standar yang ditentukan berdasarkan ASME section VIII div 1

a. Perumusan dalam kaitan dengan dimensi dalam (internal dimensions)

$\Rightarrow$ Ketebalan minimum dinding Head( $\operatorname{tmin}$ )

$$
\mathrm{t}_{\min }=\frac{p R_{i C A}}{2 S E-0,2 \mathrm{p}}+\text { C.A. }
$$

$\Rightarrow$ Tekanan kerja Maksimum ( pmax)

$$
\mathrm{p}_{\text {max }}=\frac{2 S E t_{\text {min }}}{R_{1}+0,2 \mathrm{t}_{\text {min }}}
$$

b. Perumusan dalam kaitan dengan dimensi luar ( outside dimensions )
$\Rightarrow$ Ketebalan minimum dinding Head( tmin )

$$
\mathrm{t}_{\min }=\frac{p R_{o}}{2 S E+0,8 \mathrm{P}}+\mathrm{C} \cdot \mathrm{A}
$$

$\Rightarrow$ Tekanan kerja Maksimum ( pmax )

$$
\mathrm{p}_{\text {max }}=\frac{2 S E t_{\text {min }}}{R_{o}-0,8 \mathrm{t}_{\text {min }}}
$$

c. Volume of Head

Volume Head dengan jenis Ellipstical Head dapat dihitung dengan menggunakan rumusan

$v=\left(\pi \times D^{3}\right) / 24+\left(\pi \times D^{2} \times S F\right) / 4$

\section{METODOLOGI}

Analisis kekuatan konstruksi Bladder Tank sirkulasi air panas pada sistem ORC solar kolektor R-134a diuji di depan halaman laboratorium konversi energi fakultas teknik Ibn Khaldun Bogor. Pengujian ini dilakukan dengan mengalirkan fludia air menggunakan pompa sentrifugal yang kemudian dipanaskan menggunakan solar kolektor.

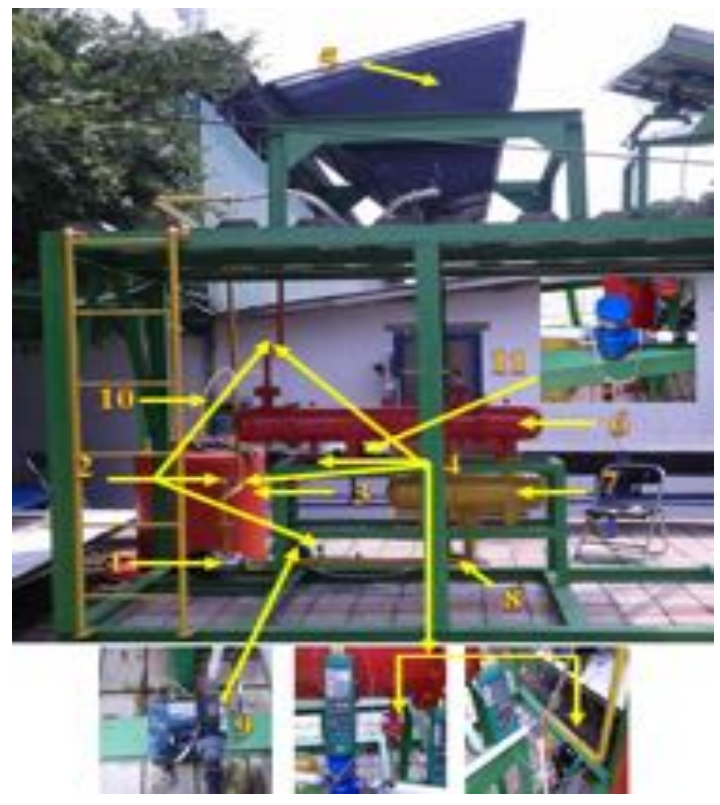

Gambar 5 Sirkulasi sistem ORC 
Peralatan yang digunakan untuk mendukung proses penelitian ini adalah sebagai berikut :

a. Pompa Sentrifugal 2 buah

b. Motor listrik, untuk memutar poros pompa.

c. Pipa, untuk sarana pengaliran fluida atau transportasi fluida.

d. Pressure gauge, untuk mengukur tekanan discharge dan suction.

e. Flowmeter, untuk mengukur debit aliran.

f. Tangki penampung air kapasitas $550 \mathrm{~L}$.

g. Termokopel, untuk mengukur temperatur air.

h. Solar Power Meter, untuk mengukur intensitas tenaga matahari.

i. Instalasi listrik, untuk kebutuhan alat uji pompa sentrifugal.

j. Selang, untuk sarana pengaliran fluida atau transportasi fluida

k. Clamp selang, untuk mengikat selang pada komponen alat uji.

I. Komputer, untuk pemodelan blader tank menggunakan software inventor fusion dan simulasi pressure drop blader tank dan Computational Fluid Dynamic(CFD) untuk simulasi.

\section{Desain Kriteria}

Bejana Tekan (Bladder Tank) yang diuji dalam karya tulis ini adalah bejana tekan silindris horisontal dengan fungsi utama sebagai tangki fluida di dalam proses sirkulasi ORC. Berikut merupakan desain kriteria Bejana tekan :

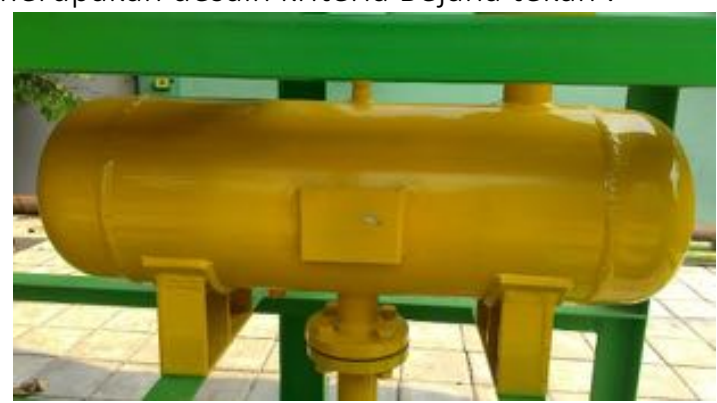

Gambar 6 Desain Bladder Tank

\section{Karakteristik Umum}

- Jenis Material : SA 106

- Material Stress value : 9600 psi Temperatur :

- Temperatur kerja maks : $90^{\circ} \mathrm{C}\left(194^{\circ} \mathrm{F}\right)$

- Temperatur kerja min: $23^{\circ} \mathrm{C}\left(73,3^{\circ} \mathrm{F}\right)$

- Temperatur Perancangan: $105^{\circ} \mathrm{C}\left(221^{\circ} \mathrm{F}\right)$ Tekanan

- Tekanan kerja $\quad$ : 14,695 psi(atm bar g)
- Tekanan Perancangan 50,763psi(3,5bar g)

- Tekanan hydrotest : Sesuai ASME VIII

- Fluida Kerja : : R 134a

- Radiography : 100\% X-RAY

- Efisiensi Sambungan :

- Dinding (Shell) : 1

- Penutup (head) : 1

Jenis dinding (shell) : Silinder

- Diameter dalam shell : 10,6299 (270 mm)

- Jenis penutup (head) : Ellips 2:1

- Panjang Bladder Tank : 31,1063 (790,1 mm)

- Ketebalan dinding (Thickness of Shell): 0,5906 in (15 mm)

- Nilai korosif (corrotion allowance) : 0,1181 in $(3 \mathrm{~mm})$

\section{Hasil dan Pembahasan}

1. Perhitungan Pada Shell

Untuk melakukan perhitungan pada Shell, terlebih dahulu harus mengetahui jenis tekanan yang bekerja pada Shell. Jenis tekanan yang terjadi pada Shell adalah circumferential joints dan longitudinal stress.

$\Rightarrow$ Circumferential Joints

$$
\mathrm{S}_{1}=\frac{p D}{4 t_{a}}=\frac{43,5113 \times 11,2205}{4 \times 0,5906}
$$

$=\frac{488,2185}{2,3624}=\underline{206,6621 \mathrm{psi}}$

$=\underline{1.424,8849 \mathrm{kPa}}$

$\Rightarrow$ Longitudinal stress

$\mathrm{S}_{2}=\frac{p D}{2 t_{a}}=\frac{43,5113 \times 11,2205}{2 \times 0,5906}$

$=\frac{488,2185}{1,1812}=\underline{413,009 \mathrm{psi}}$

\section{$=2.847,5966 \mathrm{kPa}$}

Dari Hasil perhitungan Longitudinal dan Circumferential ( hoop ) stress, dapat ditentukan bahwa material yang digunakan harus memiliki Stress value lebih dari 413,009 psi atau $2.847,5966 \mathrm{kPa}$. Dengan temperatur kerja maksimal $90^{\circ} \mathrm{C}\left(194^{\circ} \mathrm{F}\right)$ dan tekanan operasi sebesar 1 atm (14,6959 psi) maka jenis vessel termasuk kategori Vessel yang digunakan atau beroperasi pada tekanan Atmosfer dan temperatur rendah, berdasarkan Tabel 
Properties of material for Carbon and Low Alloy Steel, material yang dapat digunakan adalah material dengan spesifikasi SA-106

Analisa perhitungan ketebalan minimum dan tekanan maksimum pada Shell didapatkan berdasarkan circumferential hoop stress dan longitudinal stress :

$\Rightarrow$ Perhitungan berdasarkan circumferential hoop stress :

$$
\begin{aligned}
& \mathrm{t}=\frac{p \times D_{i}}{4 \times S} \\
& \mathrm{t}=\frac{43,5113 \times 10,6299}{2 \times 9600}=\frac{462,5208}{19200} \\
& \mathrm{t}=0,024 \text { inci }=0,6 \mathrm{~mm} \\
& \Rightarrow \text { Perhitungan berdasarkan longitudinal stress : } \\
& \mathrm{t}=\frac{p \times D_{i}}{4 \times S} \\
& \mathrm{t}=\frac{43,5113 \times 10,6299}{4 \times 9600}=\frac{462,5208}{38400} \\
& \mathrm{t}=0,012 \text { inci }=0,3 \mathrm{~mm}
\end{aligned}
$$$$
\Rightarrow \text { Ketebalan minimum dinding bejana "shell" }
$$$$
\mathrm{t}_{\text {min }}=\frac{p R_{i C A}}{S E-0,6 p}+C A
$$$$
\mathrm{t}_{\min }=\frac{43,5113 \times 5,433}{(9600 \times 1)-(0,6 \times 43,5113)}+0,1181=
$$$$
\frac{236,3969}{9600-26,1068}+0,1181
$$$$
\mathrm{t}_{\text {min }}=0,1428 \text { inci }=3,6 \mathrm{~mm}
$$$$
\Rightarrow \text { Tekanan kerja maksimum }
$$$$
p_{\max }=\frac{S E t_{\min }}{R_{i}+0,6 t}
$$$$
p_{\text {max }}=\frac{9600 \times 1 \times 0,1428}{5,1349+(0,6 \times 0,1428)}
$$$$
=\frac{1370,88}{5,3149+0,0857}=\frac{1370,88}{5,4006}
$$$$
p_{\text {max }}=253,8385 \mathrm{psi}=1.750,1547 \mathrm{kPa}
$$

Berdasarkan perhitungan teoritis, dengan menggunakan material SA 106, ketebalan minimum yang diperoleh :

‘ Berdasarkan perhitungan circumferential hoop stress : $t=0,024$ inci $(0,6 \mathrm{~mm})$
‘ Berdasarkan perhitungan longitudinal stress : t $=0,012$ inci $(0,3 \mathrm{~mm})$

Berdasarkan perhitungan menggunakan rumus ASME Section VIII div 1, dengan menggunakan material SA 106, ketebalan minimum yang diperoleh 0,1428 in $(3,6 \mathrm{~mm})$, dan tekanan maksimum yang dapat diterima oleh shell hingga sebesar 253,8385 psi = 1.750,1547 kPa (17,5 bar g). Dengan demikian Material SA 106 memenuhi syarat tekanan kerja dan temperatur kerja maksimum yang harus diatasi oleh bejana tekan pada saat proses berlangsung.

\section{Perhitungan Pada Head}

Berdasarkan data yang diperoleh, jenis Head yang digunakan untuk menutup ujung ujung dari shell adalah jenis Elliptical Head 2:1 dengan perhitungan ketebalam minimum dan tekanan maksimum pada head dapat menggunakan rumus berikut :

$\Rightarrow$ Ketebalan Minimum Head $\left(\mathrm{t}_{\min }\right)$

$\mathrm{t}_{\text {min }}=\frac{p D_{i C A}}{2 S E-0,2 p}+C A$

$=\frac{43,5113 \times 10,8661}{(2 \times 9600 \times 1)-(0,2 \times 43,5113)}+0,1181$

$=\frac{472,7981}{(19200)-(8,7022)}+0,1181$

$=0,1427 \mathrm{in}=3,6 \mathrm{~mm}$

$\Rightarrow$ Tekanan Kerja Maksimal Head ( $p_{\max }$ )

$$
\begin{aligned}
p_{\text {max }} & =\frac{2 S E t_{\text {min }}}{D_{i}+0,2 t_{\text {min }}} \\
& =\frac{2 \times 9600 \times 1 \times 0,1427}{10,6299+(0,2+0,1427)} \\
& =\frac{2739,84}{10,6299+0,3427} \\
& =249,6983 \mathrm{psi}=1.721,609 \mathrm{kPa}
\end{aligned}
$$

Berdasarkan perhitungan menggunakan rumus ASME Section VIII div 1, dengan menggunakan material SA 106, ketebalan minimum yang diperoleh 0,1427 in (3,6 mm), dan tekanan maksimum yang dapat diterima oleh Head hingga sebesar 249,6983 psi (17,2 bar g). 
3. Volume Bladder Tank

Dalam mencari volume Bladder Tank terlebih dahulu harus mencari volume shell dan Head. Untuk menghitung Volume shell kita dapat menggunakan rumus tabung, yaitu luas alas $x$ tinggi. Jadi rumus yang digunakan adalah

$$
\begin{aligned}
v & =\pi \times r^{2} \times t \\
& =3.14 \times 135^{2} \mathrm{~mm} \times 600 \mathrm{~mm} \\
& =34335900 \mathrm{~mm}^{3}=34,3359 \text { Liter }
\end{aligned}
$$

Untuk menghitung Head dengan jenis elliptical head adalah

$v=\left(\pi \times D^{3}\right) / 24+\left(\pi \times D^{2} \times S F\right) / 4=$ $\left(3,14 \times 270^{3} \mathrm{~mm}\right) / 24+\left(3,14 \times 270^{2} \mathrm{~mm} \times 20 \mathrm{~mm}\right) / 4$

$=2575192,5 \mathrm{~mm}+1144530 \mathrm{~mm}$

$=3719722,5 \mathrm{~mm}^{3}=3,7197$ Liter

Setelah mendapatkan volume shell dan head maka dapat ditemukan volume Bladder Tank tersebut dengan menjumlahkan antara volume shell dan head

Volume Bladder Tank = volume of shell + volume of head

$=34335900 \mathrm{~mm}^{3}+3719722,5 \mathrm{~mm}^{3}$

$=38055622,5 \mathrm{~mm}^{3}=38,0556$ Liter

\section{Simulasi Pressure Drop Bladder Tank}

Simulasi pressure drop menggunakan software Computational Fluid Dynamic (CFD) student version. Model turbulensi yang digunakan pada simulasi ini yaitu model turbulensi K-epsilon, digunakan model turbulensi k-epsilon karena model ini sudah tervalidasi, Model ini telah berhasil menghitung berbagai macam variasi aliran thin shear layer serta recirculating flow tanpa menyesuaikan dengan model tiap kasus. Beberapa tahapan dilakukan untuk melakukan simulasi CFD diantaranya sebagai berikut:

\section{Buka File Model CFD Blader Tank}

Pilih dan buka file model Blader Tank dengan

Format cfdst.

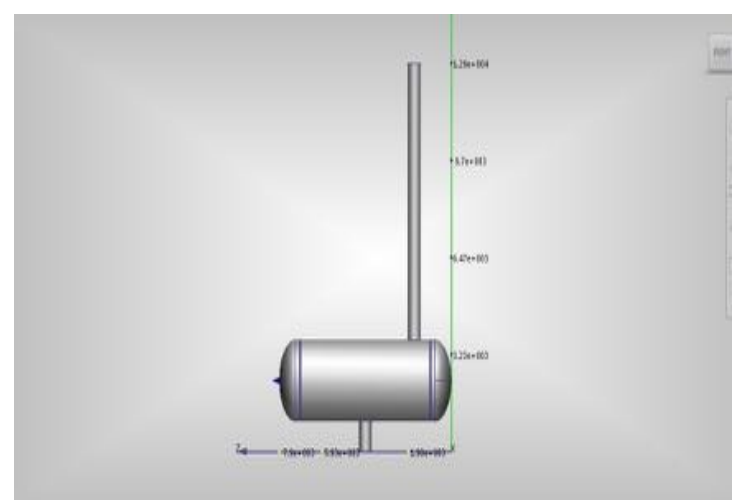

Gambar 7. Model CFD Blader Tank.

\section{Geometry Tools}

Satuan yang dipilih pada tahapan ini yaitu milimeter, kemudian tahapan selanjutnya memilih void fill untuk menutupi lubang pada sisi inlet dan outlet.

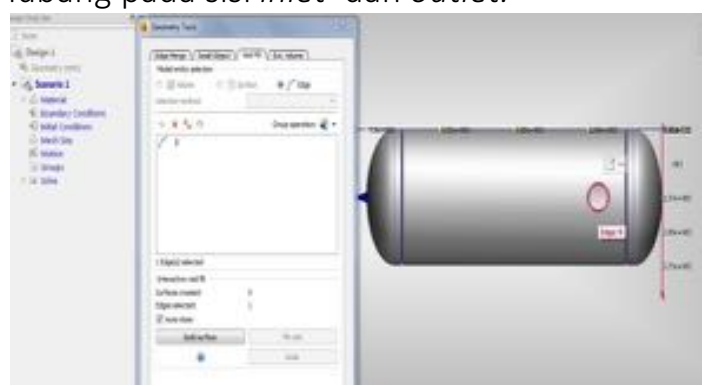

(a)

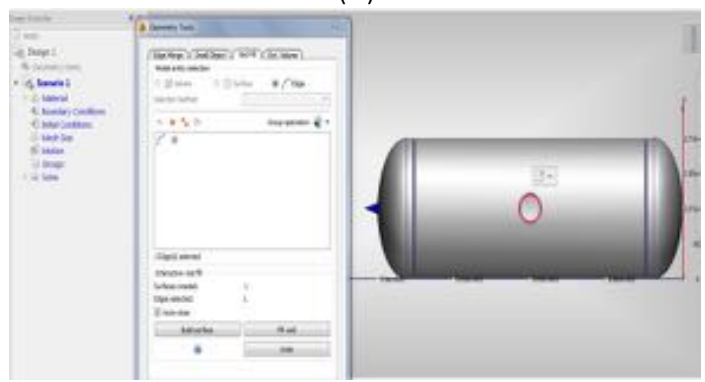

(b)

Gambar 8. (a) Void Fill pada sisi inlet, (b) Void Fill pada sisi outlet.

\section{Material}

Bahan material blader tank yang di analisis yaitu carbon steel SA 106 dan Jenis fluida yang akan di analisis yaitu air dengan suhu $37^{\circ} \mathrm{C}$. 


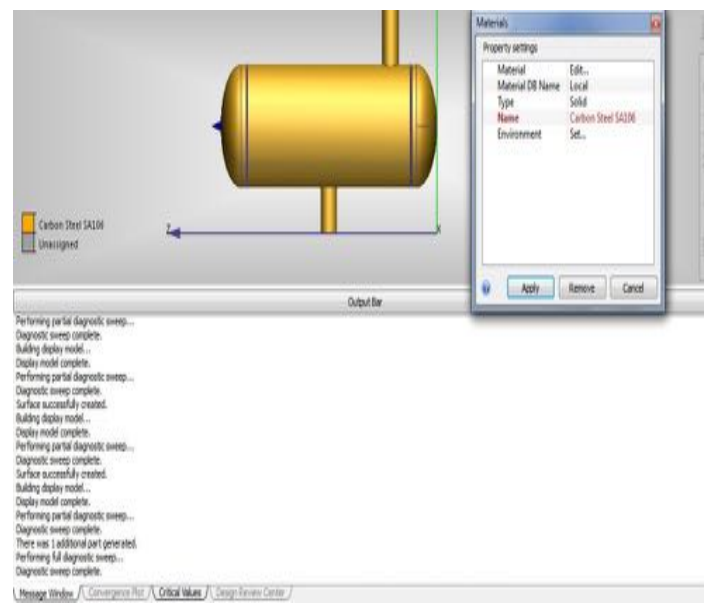

Gambar 9. Property setting Material Fluida.

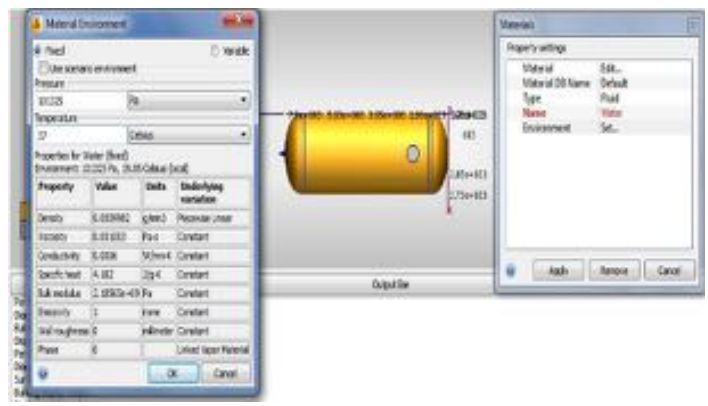

Gambar 10. Property setting Material Solid.

\section{Boundary Conditions}

Volume Flow rate pada sisi Inlet yang di analisis sebesar $0,000875 \mathrm{~m}^{3} / \mathrm{s}$, waktu aliran steady state, direction reverse normal dan pressure yang dianalisis $0 \mathrm{~Pa}$ gage.

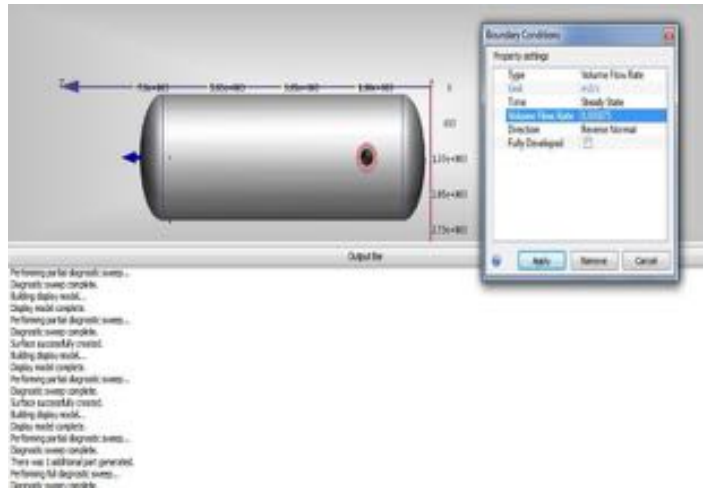

Gambar 11. Boundary Conditions Volume Flow Rate

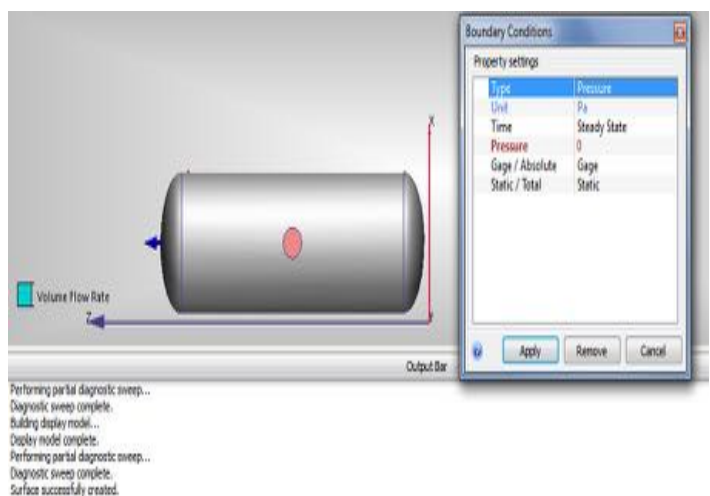

Gambar 12. Boundary Conditions Pressure. 5. Mesh Size

Mesh Size yang di analisis yaitu Autosize.

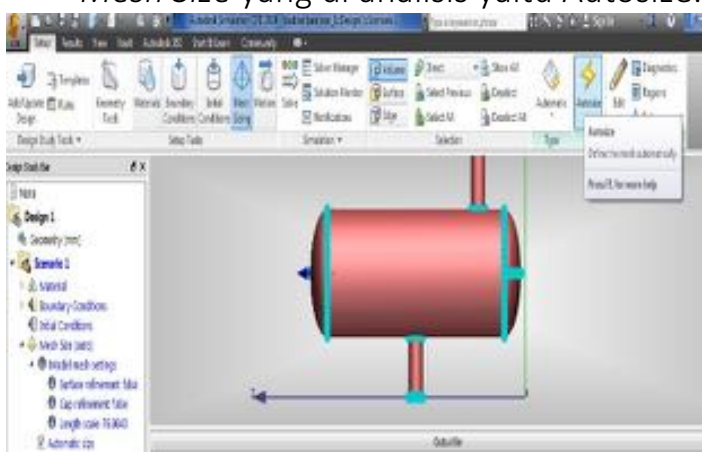

Gambar 13. Mesh Size.

6. Hasil simulasi Pressure Drop Blader Tank.

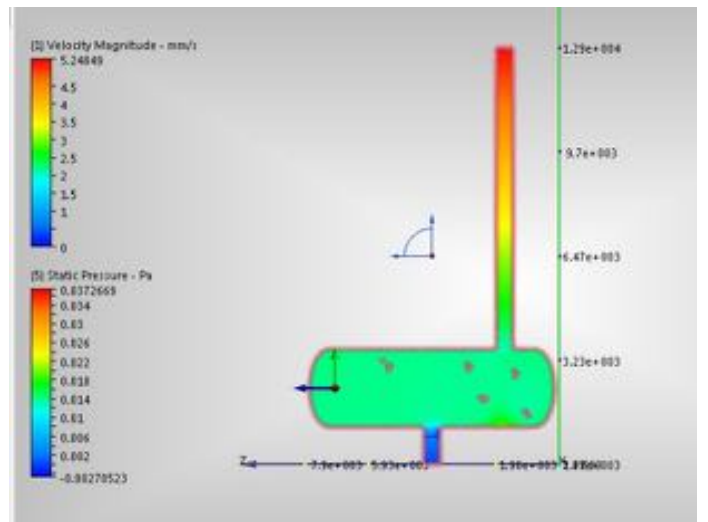

Gambar 14. Hasil Simulasi CFD Blader Tank.

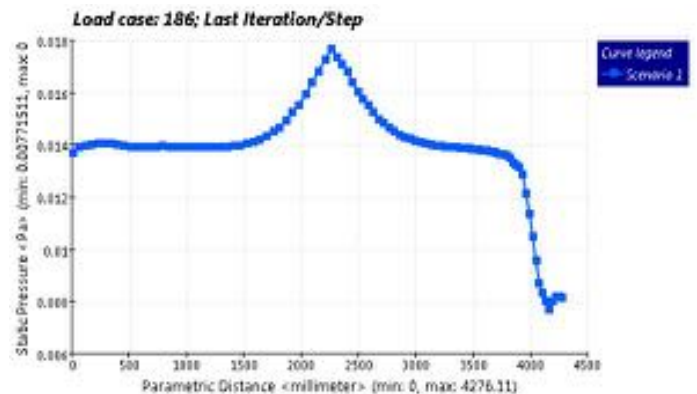

Gambar 15. Grafik Distribusi Tekanan Bladder Tank.

Tabel 1 Data Hasil simulasi Blader Tank. 


$\begin{array}{ll}\begin{array}{l}\text { Turbulent } \\ \text { incompressible } \\ \text { Turbulent Model }\end{array} & \begin{array}{l}\text { On } \\ \text { Standard } \\ \text { Epsilon }\end{array} \\ \begin{array}{l}\text { Intelligent Wall } \\ \text { Formulation } \\ \text { Mass Flow In }\end{array} & \text { Off } \\ \begin{array}{l}\text { Volume Flow in } \\ \text { Inlet Bulk }\end{array} & 869.023 \mathrm{~g} / \mathrm{s} \\ \begin{array}{l}\text { Pressure } \\ \text { Outlet Bulk } \\ \text { Pressure } \\ \text { Mass Flow Out } \\ \text { Volume Flow } \\ \text { Out }\end{array} & -87500 \mathrm{~mm}^{3} / \mathrm{s} \\ & -858.167 \mathrm{~g} / \mathrm{s} \\ & -864069 \mathrm{~mm}^{3} / \mathrm{s}\end{array}$

Dilihat dari hasil simulasi $P_{1}=0.014$ pa dan $P_{2}=0.008 \mathrm{pa}$, untuk menghitung head losses menggunakan rumus dari penurunan rumus bernoulli.

$$
\begin{aligned}
\frac{\Delta \mathrm{P}}{\rho g}=\frac{P_{1-} P_{2}}{\rho g}= & \frac{0.014-0,008}{933,37 \times 9,81} \\
& =6,6 \times 10^{-7} \mathrm{~m}
\end{aligned}
$$

\section{KESIMPULAN}

Perancangan bejana tekan (Bladder Tank) harus diperhatikan secara cermat, agar tidak mengalami hal-hal yang terjadi di luar aturan saat suatu proses produksi berlangsung. Perancangan bejana tekan ini akan sangat dipengaruhi oleh suhu kerja dan tekanan kerja dari materi yang akan diproses. Pemilihan material dan bentuk bejana tekan yang tepat dan semua parameter tersebut harus diperhatikan secara cermat agar proses instalasi dan konstruksi sesuai dengan spesifikasi yang diinginkan.

Berdasarkan spesifikasi yang telah ditetapkan sebelumnya analisa dan perhitungan yang dilakukan penulis maka kesimpulan yang didapat dari hasil perhitungan perancangan bejana tekan (Bladder tank) adalah sebagai berikut:

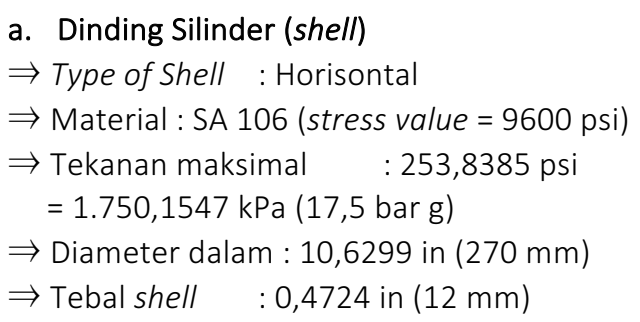

$$
\begin{aligned}
& \Rightarrow \text { Corotion Allowance }: 0,1181 \mathrm{in}(3 \mathrm{~mm}) \\
& \Rightarrow \text { Panjang Shell : 23,6220 in }(600 \mathrm{~mm}) \\
& \Rightarrow \text { Volume Shell }: 34335900 \mathrm{~mm}^{3} \\
& \quad=34,3359 \text { Liter }
\end{aligned}
$$

b. Penutup (Head)

$\Rightarrow$ Type of Head : Horisontal

$\Rightarrow$ Material : SA 106 (stress value = 9600 psi)

$\Rightarrow$ Tekanan maksimal : 249,6983 psi $=1.721,609 \mathrm{kPa}(17,2$ bar g)

$\Rightarrow$ Diameter dalam : 10,6299 in (270 mm)

$\Rightarrow$ Tebal Head : 0,4724 in (15 mm)

$\Rightarrow$ Corotion Allowance $\quad: 0,1181$ in (3 mm)

$\Rightarrow$ Volume Head : $3719722,5 \mathrm{~mm}^{3}$ = 3,7197 Liter

\section{c. Volume Bladder Tank}

Volume Bladder Tank= volume of shell + volume of head

$=34335900 \mathrm{~mm}^{3}+3719722,5 \mathrm{~mm}^{3}$

$=38055622,5 \mathrm{~mm}^{3}=38,0556$ Liter

\section{d. Head Loss}

Hasil Simulasi Perhitungan Head Loss didalam Bladder Tank adalah sebesar 0,00000066 m

Dengan demikian Kapasitas Bladder Tank yang terpasang terlalu besar untuk kebutuhan sistem sirkulasi air panas pada sistem ORC solar kolektor R-134a.

\section{REFERENSI}

[1] E. Bou Lawz Ksayera. 2011. Design of an ORC system operating with solar heat and producing sanitary hot water, Elsevier, Volume 6 : pp 389-395, Paris.

[2] Putra, Riki Candra. 2017. Perancangan Bejana Tekan Kapasitas 5 M3 Dengan Tekanan Desain 10 Bar Berdasarkan Standar ASME 2007 Section VIII DIV 1. Tangerang: Jurnal Teknik. 2-7.

[3] White, Frank.M. (1986). Fluid Mechanics Fourth Edition, McGraw-Hill, University Of Rhode Island.

[4] Verlag Europa-Lehrmittel. 1997. Tabellenbuch metall. Nourney, Vollmer Gmbh \& Co.

[5] Effendi, Riki. 2014. Optimasi Kekuatan Horizintal Vessel Menggunakan Analisis Elemen Hingga. Jakarta: Seminar Nasional Sains dan Teknologi 2014. 
[6] Aziz, A., Hamid, A., \& Hidayat, I. 2014. Perancangan Bejana Tekan (Pressure Vessel) Untuk Separasi 3 Fasa. Jakarta: SINERGI Vol. 18, No 1.

[7] Lloyd E. Brownell and Edwin H. Young.1959. Equipment Design

[8] Eugene F. Megyesy.1998. Pressure Vessel Handbook. Pressure Vessel Handbook publishing.USA

[9] ASME Boiler and Pressure Vessel code, section VIII div 1.2010, Rules for Construction of Pressure Vessel, July 1, 2010. 